\title{
波動周期の増加に伴う準定常境界層への漸近挙動に 関する実験的研究
}

川村育男*・アーマドサナ**・田中 仁***

\section{1. 研究の目的}

波浪による流速場や底面せん断力を知ることは地形変 動や土砂移動の算定のために重要である.そこで現在ま でに, 波動境界層に関して数多くの研究がなされている.

通常, 「波動境界層」と言えば, 暗黙の内に水深に比べ 境界層厚がきわめて薄い状態を想定している。しかし， 汀線に近い極浅海域や長周期性の波動下においてはこの ような仮定が満たされず，むしろ準定常的な流れ場が形 成される.そこで, 著者らはこのような境界層を対象と して理論的研究を行い, 通常の波動抵抗則域加ら準定常 抵抗則域への遷移限界や, 一様勾配海浜上を伝搬する波 動下における抵抗特性の変化に関する検討を行った (Tanaka and Shuto, 1994 ; サナ・田中，1995).ただし, これらの研究は単純化された乱流モデルに基づくもので あり，その理論自体の検証は行われていなかった。

そこで, 本研究では通常の波動境界層から準定常状態 の境界層までを発生させることの出来るU字管振動流 装置を作製して実験を行い，これら二種の境界層の間で の遷移特性に関する検討を行った。なお，同様な現象を 扱ったものとしては, 波動水槽を用いて行われた Yalin and Russell (1966) による実験的研究がある.

\section{2. 実験装置と実験方法}

図一1に実験装置の概略を示す，2つの連動するピス トンによりU字管の左右に交互に空気を出入りさせ, 内 部の水に振動を発生させる. 測定部の壁面には高さ 5.4 $\mathrm{mm}$ の三角粗度を $12 \mathrm{~mm}$ 間隔で貼り付けた（図一 2 参 照).ピストンのモーターの速度及び振幅を変えることに より，通常の波動境界層加ら準定常波動境界層に至る広 範囲での実験が可能である.流速測定はU 字管水平部の アクリル部（長さ $2.5 \mathrm{~m}$, 幅 $0.36 \mathrm{~m}$, 高さ $0.06 \mathrm{~m}$ ) の中 央部において, 粗度の頂部から管路中央までの 18〜26 点 についてレーザードップラー流速計を用いて行った。サ ンプリング間隔 $10 \mathrm{~ms}$ または $20 \mathrm{~ms}$ で 50 波のデータを

\footnotetext{
* 学生会員 東北大学大学院工学研究科

** 正会 員 M.Eng. 東北大学助手 大学院工学研究科

*** 正会員 工 博 東北大学教授 大学院工学研究科
}

とり，アンサンブル平均して 1 周期内の速度分布や乱れ 強度分布を得た。

実験は定常流を 5 ケース, 振動流を 14 ケース行った。 なお, 粗度の大きさ, 間隔から $\Delta z$ (仮想底面高さ), $z_{0}$ (粗 度長さ) を求める普遍的な公式などは確立されていない. そこで本研究では各ケース毎に壁面近傍の速度分布に対 数則を当てはめ実験的にこれらを求めた. その結果, $z_{h} / z_{0}$ $\left(z_{h}\right.$ : 壁面から管中心までの高さ) は 15.6 から 21.3 であ り, 平均値は 18.7 であった。

図一2に，以下に用いる記号の定義を示す.

摩擦係数 $f$ は (1) 式の対数則を用いて得られた摩擦 速度 $U_{*}$ の最大值と実験から求められた断面平均流速 $U_{0}$ の最大值を（2）式に代入することにより得られる.

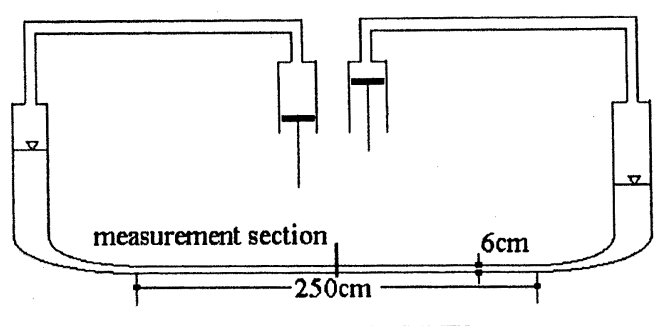

OSCILLATING TUNNEL

図一1 実験装置

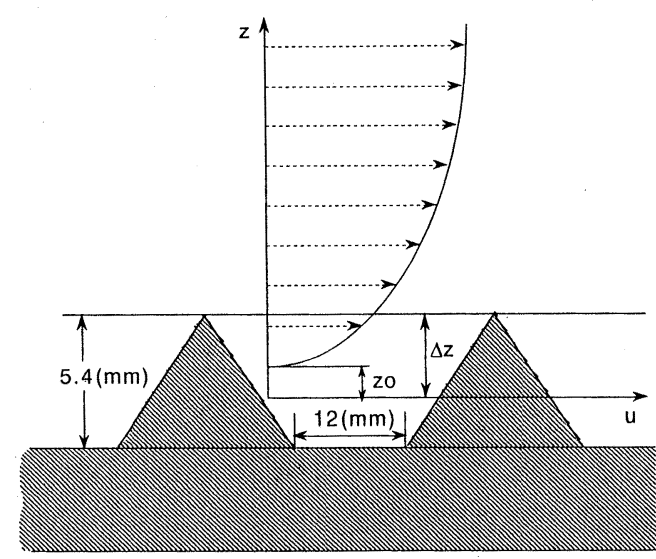

図一2 記号の定義 
表 -1 実験条件

\begin{tabular}{c|c|c|c|c}
\hline $\begin{array}{c}\text { 実 験 } \\
\text { ケース }\end{array}$ & $\begin{array}{c}T \\
(\mathrm{~s})\end{array}$ & $\begin{array}{c}U_{0} \\
(\mathrm{~cm} / \mathrm{s})\end{array}$ & $U_{0} / \sigma z_{0}$ & $f$ \\
\hline $\mathrm{Q} 01$ & 4.86 & 80.8 & 394 & 0.094 \\
\hline $\mathrm{Q} 02$ & 3.33 & 36.8 & 149 & 0.119 \\
\hline $\mathrm{Q} 03$ & 5.39 & 19.7 & 129 & 0.127 \\
\hline $\mathrm{Q} 04$ & 2.61 & 55.4 & 176 & 0.111 \\
\hline $\mathrm{Q} 05$ & 3.52 & 104.4 & 327 & 0.103 \\
\hline $\mathrm{Q} 06$ & 7.28 & 50.8 & 360 & 0.089 \\
\hline $\mathrm{Q} 07$ & 4.06 & 100.8 & 373 & 0.093 \\
\hline $\mathrm{Q} 08$ & 5.50 & 69.8 & 363 & 0.090 \\
\hline $\mathrm{Q} 09$ & 3.08 & 145.4 & 427 & 0.097 \\
\hline $\mathrm{Q} 10$ & 4.32 & 77.3 & 363 & 0.091 \\
\hline $\mathrm{Q} 11$ & 3.61 & 81.9 & 330 & 0.091 \\
\hline $\mathrm{Q} 12$ & 3.57 & 65.7 & 271 & 0.096 \\
\hline $\mathrm{Q} 13$ & 3.54 & 50.0 & 215 & 0.104 \\
\hline $\mathrm{Q} 14$ & 3.55 & 19.3 & 48 & 0.745 \\
\hline
\end{tabular}

$$
\begin{aligned}
& u=\frac{U_{*}}{\kappa} \ln \frac{z}{z_{0}} \cdot \\
& f=2\left(\frac{U_{*}}{U_{0}}\right)^{2}
\end{aligned}
$$

ここで, $\kappa$ : カルマン定数 $(=0.4), z$ : 鉛直座標である.

振動流の実験条件と得られた $f$ の値を表一 1 に示す. 表中での $\sigma$ は角振動数である.

\section{3. 実験結果と考察}

\section{（1）流速分布}

図一3(a)〜 ( c) に最も非定常性が強く波動的な振る舞 いを示すものと，反対に定常的な挙動を示すもの，及び その中間のケースでの速度分布を示す．図一 3 (a) は周期 が短い, 非定常性の強い時の流速分布であり, overshoot 現象や位相のずれ，また管路中央付近で速度勾配がゼロ になる領域が見られるなど，波動境界層に特徴的な現象 が現れている。一方，図一3(c)には周期が長い，定常性 の強いときの流速分布が示されている. 図一 3 (a) と異な り，境界層が管路中央まで発達し，位相差のズレも小さ いなど，準定常的な特徴が見られる．図一3(b)の実験で は，上記のケースの中間的な振る舞いをしている．現在 までにこのような速度分布の変化を報告した実験例はな い.

\section{（2）乱 れ強度}

図一-4(a)，図一-4(b) に図-3(a)，(c) で示した平均流 速分布に対応する乱れ強度のコンター図を示す．図一 （a）は周期が短いときの変動成分であるが，これを見る と非定常性が強いときの乱強度の分布は，特に管路底

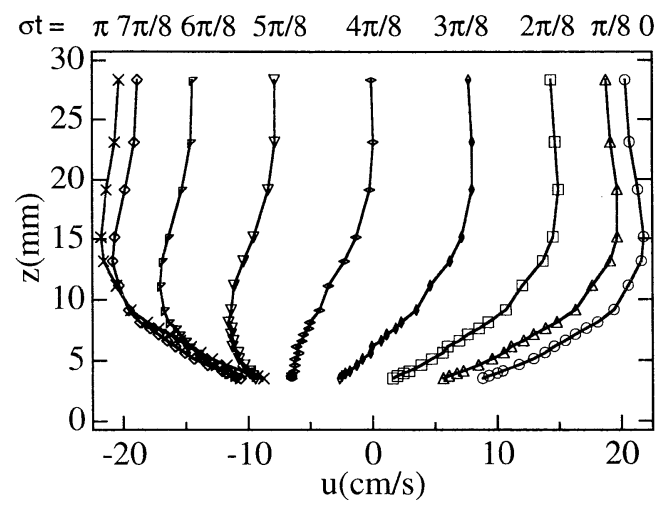

(a) Run Q03

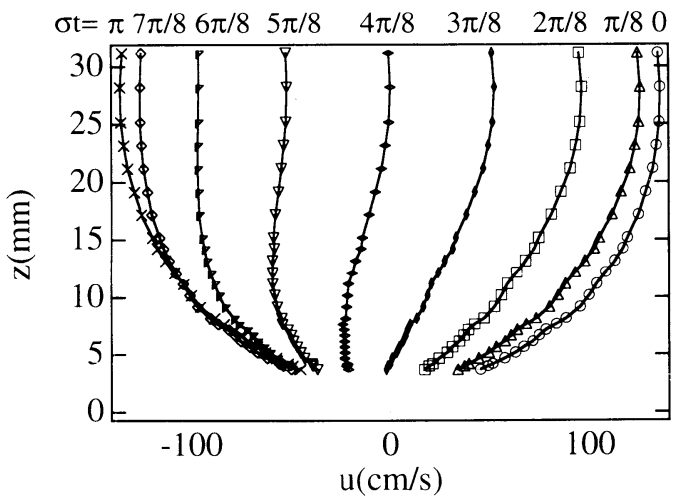

(b) Run Q05

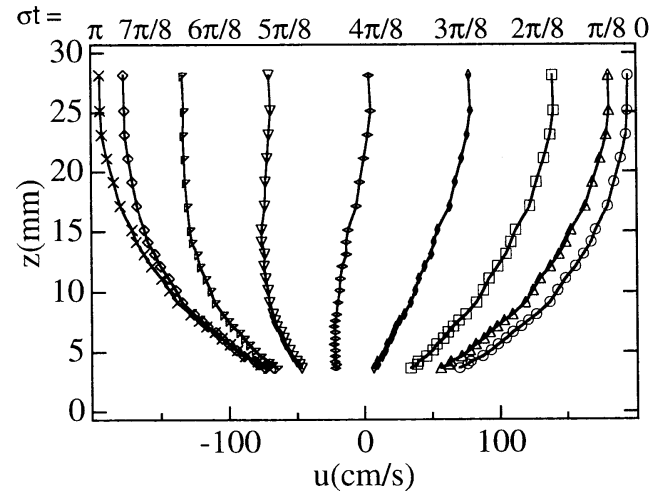

(c) Run Q09

図一 3 流速分布

面部付近において顕著だが位相のズレが大きい。また， 管路中央付近で乱れ強度の大きさがかなり小さくなって いる。一方，図一4(b)に示されるように周期の長いとき の乱れ強度の分布では，全体的に位相のズレがあまりみ られず，速度の大小に応じて乱れ強度が増減している様 子が窺える。 


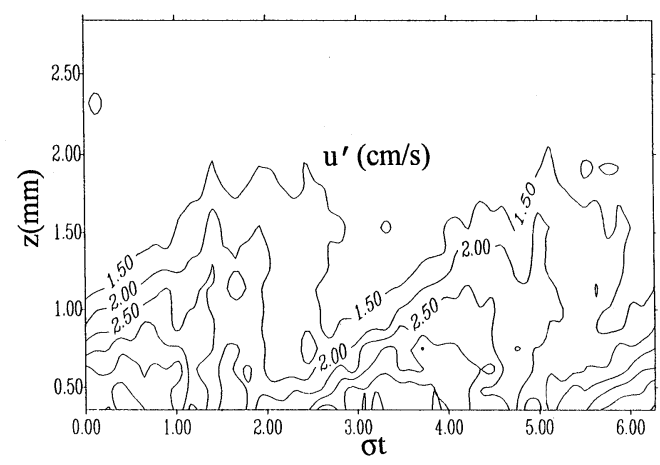

(a) Run Q03

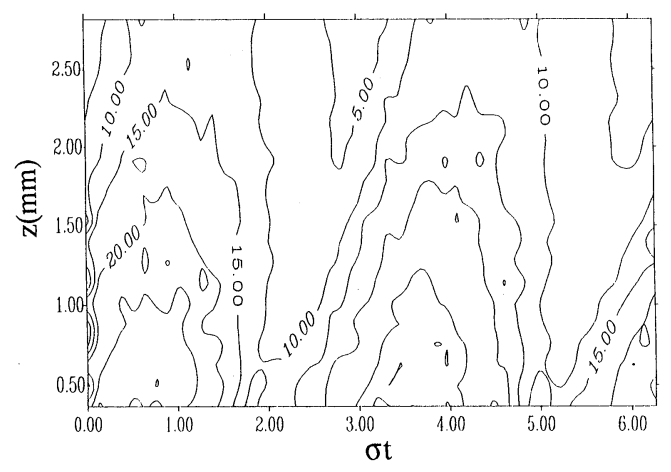

(b) Run Q09

図-4 乱れ強度

\section{(3) 摩擦係数}

図一5(a) に本研究による摩擦係数 $f$ を示す。図には Jonsson(1980), Kamphuis (1975), 及び Tanaka (1992) の波動摩擦係数式並びに Tanaka ら（1994）による波動 抵抗則から定常抵抗則への遷移摩擦係数の理論値も示し た. 周期が短い時, すなわち $U_{0} / \sigma z_{0}$ の值が小さい時の実 験值は, Jonsson, Kamphuis の式に比較的近い值を示す. $U_{0} / \sigma z_{0}$ の増加に伴い定常流の実験值 (○印)に漸近して行 くことが判る. $U_{0} / \sigma z_{0}$ 付近で Tanaka の摩擦係数は他の 二者と差が大きい. このため, 実験に現れた遷移の様子 は Tanaka and Shuto の理論と異なっている.

図一5(b) には比較のために Yalin and Russell (1966) のデー夕を示した.これは図-5(a)に比べて $U_{0} / \sigma z_{0}$ の值 ははるかに大きいものとなっている。図一5(a)に比べば らつきが大きいものの, 理論と同様な遷移を示している.

\section{（4）境界層厚さ}

境界層厚さ $\delta$ の変化を図一6に示す. 本研究では, 流速 振幅が最大となる点の壁面からの距離を境界層厚さとす る Jensen et al. (1989) の定義を用いた。図で $a_{m}$ は水粒 子の軌道振幅である. 波動下でのデータとして, Jonsson and Carlsen (1976), Jensen et al. (1989), Sleath (1987)

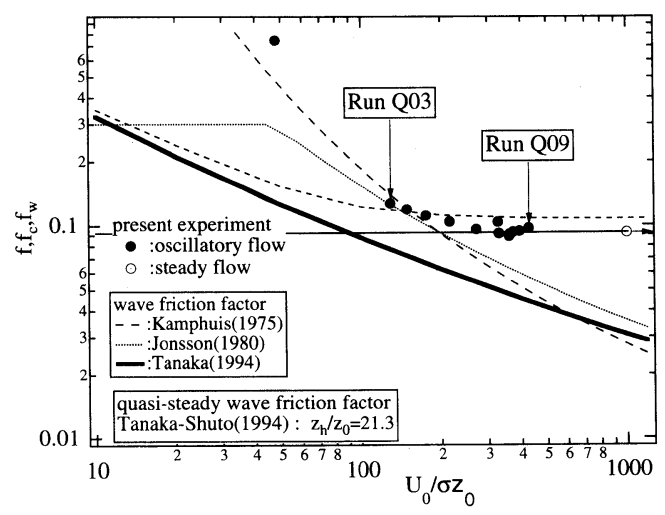

(a) 本研究の実験結果

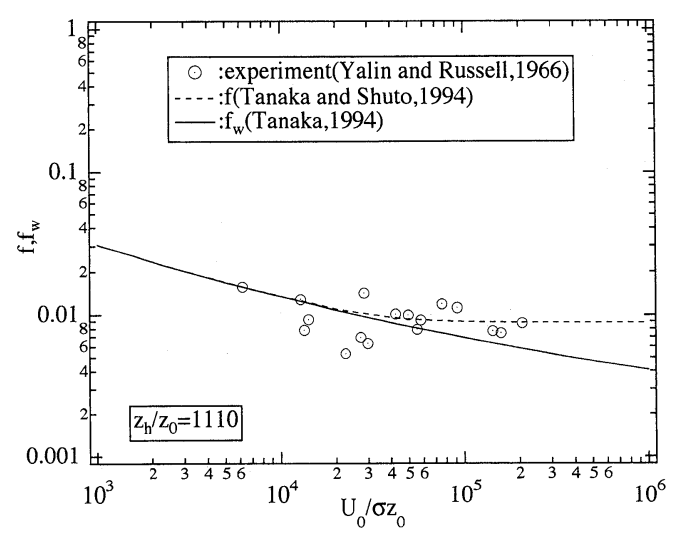

(b) Yalin and Russell の実験結果

図一5 摩擦係数

の値もプロットした， $U_{0} / \sigma z_{0}$ が小さい時，本実験の值は Jensen らのデータを左に外挿した直線上に位置する。こ のことから，本実験の結果は過去の実験データと良い一 致を見せていることが分かる．横軸の值が増加するにつ れて実験值はこの直線からはずれ，定常流で成立する $\delta$ $=z_{h}$ に移行して行く様子が認められる. 同図から得られ る遷移限界での $U_{0} / \sigma z_{0}$ 值は約 300 であり, 図一5(a)で定 常流抵抗則への移行がほぼ完了する点でのそれに一致し ている。なお, 図中には遷移後の直線として, 本実験の $z_{h} / z_{0}$ の平均值 18.7 に対するもののみを示したが, この 直線は各実験での $z_{h}$ に対応して異なるものである. Jensen Jonssonの用いたU 字管実験では $z_{h} / z_{0}=18.7$ の 直線より右側の領域に遷移が表れることになる.

\section{（5）準定常抵抗則域の判定条件}

以上に示した遷移現象は急激な変化を伴うものではな く, 緩慢に生じる.このため, 遷移点を明確に定義する ことは困難であるが,ここでは, 図一5に示された準定常 流域の摩擦係数を横軸に平行に外插し, 波動摩擦係数と 


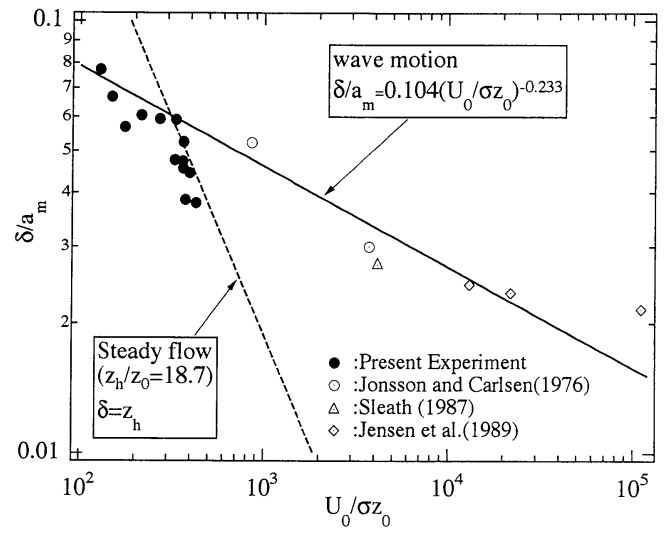

図一6 境界層厚さ

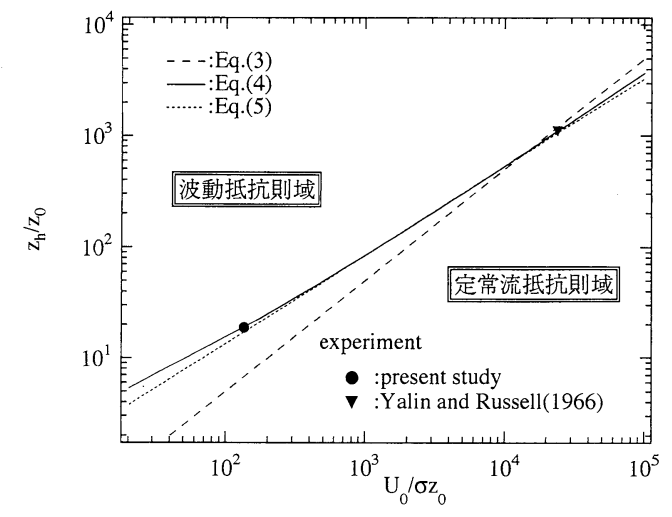

図一7 準定常抵抗則域の判定図

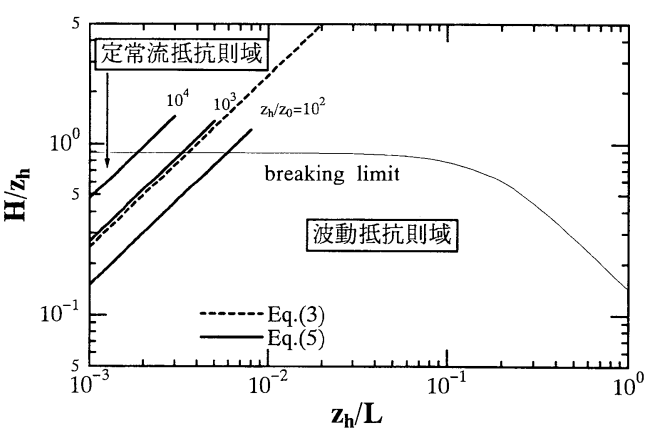

図一8 波の諸元で表された準定常抵抗則域判定図

に対して,今回新たに得られた式（5）は粗度長さの関 数になっている.

式（5）で表された判定条件を波の諸元で置き換える ことにより（6）式を得る.

$$
\frac{H}{z_{h}}=47.9\left(\frac{z_{h}}{z_{0}}\right)^{0.25} \frac{z_{h}}{L}
$$

これを砕波指標とともに図一 8 に示す.ここで, $H$ : 波 高, $L$ : 波長である.図中にはすでに提案した理論による 準定常判定条件式と先に示した近似式も示してあるが, 差異が見られる．また，長波の領域においても準定常境 界層とはならない領域が広いということに注意しなけれ ばならない。これは，抵抗則の準定常性は水深と境界層 の比に支配されるのに対し，波動の分類は全く異なる指 標（水深/波長）によっているためである.

\section{4. ま と め}

波動運動の水粒子軌道振幅を徐久に増加させることに より, 時々刻々の境界層内の速度分布が波動運動に特徵 的なものから準定常的な振る舞いを示すものに変化する
式（3）には無次元表示のために両辺に $z_{0}$ が含まれて いるが，実質的に判定式（3）は $z_{0} に$ 依存しない。これ 
ことが実験的に示された.また，乱れ強度の時空間特性 についても同様な変化が見られた。実験により得られた 摩擦係数と境界層厚さを調べることにより，この様な遷 移過程をより明僚に示すことができた，実験結果をもと に，波動抵抗則と準定常抵抗則とを使い分けるための判 定基準が得られた。

謝辞：本研究の実験に際し, 東北大学工学部山路弘人 技官より多大な助力を得た。また，本研究に対して文部 省科学研究費の補助を受け, 本論文の公表に際し, 小川 基金の補助を受けた。ここに記して謝意を表する。

\section{参 考 文 献}

田中 仁・Ahmad Sana（1995)：長周期性波動下に扔ける底面 摩擦の特性, 海岸工学論文集, 第 42 巻, pp. 36-40.

Jensen, B. L., B. M. Sumer and J. Fredsoe (1989): Turbulent oscillatory boundary layer at high Reynolds numbers, J.
Fluid Mech., Vol. 206, pp. 265-297.

Jonsson, I. G. (1980): A new approach to oscillatory rough turbulent boundary layers, Ocean Eng., Vol. 7, pp. 109$152+567-570$.

Jonsson, I. G. and N. A. Carlsen (1976): Experimental and theoretical investigation in an oscillatory turbulent boundary layer, J. Hyde. Res., Vol. 14, No. 1. pp. 45-60.

Kamphuis, J. W. (1975): Friction factor under oscillatory waves, J. Waterways, Harbors and Coast. Eng. Div., Vol. 101, No. WW2, pp. 135-144.

Sleath, J. F. L. (1987): Turbulent oscillatory flow over rough beds, J. Fluid Mech., Vol. 182, pp. 369-409.

Tanaka, H (1992): An explicit expression of friction coefficient for wave-current coexistent motion, Coastal Eng. in Japan, Vol. 35, No. 1, pp. 83-91.

Tanaka, H. and N. Shuto (1994): Quasi-steady property of bottom friction in a wave boundary layer, Proc. Int. Symp. : Waves-Physical and Numerical Modelling, pp. 1570-1579.

Yalin, M. S. and R. C. H., Russell. (1966): Shear stresses due to long waves, J. Hydr. Res., Vol. 4, No. 2, pp. 55-98. 